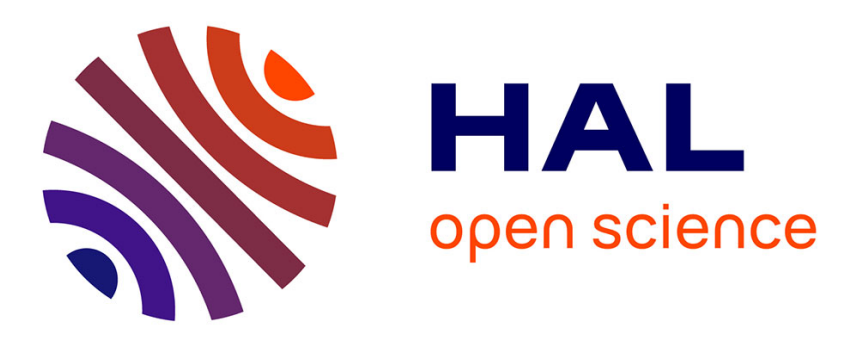

\title{
The 'hidden costs' of water provision: New evidence from the relationship between contracting-out and price in French water public services
}

Simon Porcher

\section{- To cite this version:}

Simon Porcher. The 'hidden costs' of water provision: New evidence from the relationship between contracting-out and price in French water public services. Utilities Policy, 2017, 48, pp.166-175. hal02002309

\section{HAL Id: hal-02002309 \\ https://hal.science/hal-02002309}

Submitted on 31 Jan 2019

HAL is a multi-disciplinary open access archive for the deposit and dissemination of scientific research documents, whether they are published or not. The documents may come from teaching and research institutions in France or abroad, or from public or private research centers.
L'archive ouverte pluridisciplinaire HAL, est destinée au dépôt et à la diffusion de documents scientifiques de niveau recherche, publiés ou non, émanant des établissements d'enseignement et de recherche français ou étrangers, des laboratoires publics ou privés. 


\title{
The 'Hidden Costs' of Water Provision: New Evidence from the Relationship between Contracting-Out and Price in French Water Public Services
}

\author{
Simon PORCHER *
}

January 31, 2019

\begin{abstract}
In France, the management of public services such as water or sanitation can be done by the municipal council or contracted out to a private operator. This paper quantifies the impact of the choice of contracting out the management of water public services on price. It uses a unique dataset of utilities with unusual detailed financial indicators, such as debt of the water public service. We find evidence that private management is associated with higher prices on average ceteris paribus but that this difference disappears when we account for the 'hidden costs' of water, i.e. the price taking into consideration debt refunding of the public service which could increase the price in the following years. Indeed, private management is characterized by higher tariffs but lower debt level so that the price ensure the full-costs recovery while under public management, prices are set at a lower level than under private management but with a higher debt of the public service.
\end{abstract}

JEL Codes: L14-L33-L95. Keywords: public-private partnerships, water, contracting out, debt, public services.

*Sorbonne Business School, 8 bis rue Croix Jarry, 75013 Paris, France, porcher.iae@univ-paris1.fr. I am grateful to Suez for their help in the collection of the dataset. I thank Decio Coviello, John de Figueiredo, Ricard Gil, Francine Lafontaine, Brian Silverman, Stephane Saussier and participants at various seminars and conferences for helpful comments. The usual disclaimer applies. 


\section{Introduction}

In France, as in most European countries, municipalities must provide local public services that have public good characteristics. Water is one of these public services: municipalities monitor prices, control entry and exit of firms into the market, organize competition and ensure uninterrupted service. The service can be managed in-house or be contracted out to a private operator using a public-private arrangement. Whatever the management system, the local authorities set the objectives such as an uninterrupted service, resource conservation and affordable prices - and have to enforce them.

There are two conventional wisdoms in government contracting for industrial public services. On the one hand, critics of contracting out argue that private operators charge higher prices than governments in order to get a margin out of the exploitation of the public service. Defenders of contracting-out explain that prices are higher under private management because costs are covered and service quality is better. On the other hand, critics of government provision underline the fact that governments might keep prices at a low-level for electoral reasons and subsidy public services using debt. This paper studies the difference of prices between public and private management in the French water public services. It particularly sheds light on whether there are differences of pricing, regarding service quality and debt-levels, between public and private management.

A particular feature of France is that public services such as water or transportation, for which municipalities have to produce the public good, are characterized by special accounts - 'supplementary budget' - so that the debt of the public service cannot be refunded by an increase in municipal taxes for example. In the rule of the law, there is thus permeability between the budget of the municipality and the budget of the water public services and it is not possible to cross-subsidy water using taxes or margins from other public services. The incidence of the municipal water budget's debt has largely been ignored in previous research on the industry, most probably because these indicators are difficult to collect, as municipalities and private operator have no obligations to publish it online. If one assumes that directly managed services underprice their output, e.g. by funding investments using debt rather than increasing fees, then there should be significant differences of indebtness levels between directly managed and contracted out water services, which could in fine result in differences of prices paid by users.

This paper uses an original dataset of 116 water utilities in 2009 serving more than 9 million inhabitants in France. Our results show that private management is associated with lower public service's debt as compared to public management. We then recompute the current value of the debt to be refunded by each user under different hypotheses on the path of debt-refunding. To make things simple, we assume that debt can either be refunded in one shot (i.e. this year), in the next 5 years or in the next 10 years. We then recompute current prices to consider debt refunding using these several hypotheses. For example, if the debt per user in a given municipality is 30 euros, then it means that a user in this municipality should pay a 'real price' of his current bill plus 30 euros for this year. We call the addition of the effective price paid and the price taken into account the 'hidden costs' of water. Our results show that when one considers the hidden costs of water, there are no differences between direct management and contracting out ceteris paribus. 
Such a result provides a powerful explanation to the price premium found in favor of public management in many studies .

The paper is linked to a long-established research theme in economics which studies performance across organization forms, public provision versus private provision. Economists have been keen on analyzing the public vs. private ownership debate in public utilities. A major theme in the literature is that public ownership is inherently less efficient than private ownership (Alchian and Demsetz [1972]) since ownership is diffused among all members of society, and no member has the right to sell their share. Given these aspects of public ownership, there is little economic incentive for any owner to monitor the behavior of the firm's management. Overall, we would expect markets to better allocate resources and reduce prices but also in the competitive market (see Davies [1971],Caves and Christensen [1980] and Vining and Boardman [1992] for early empirical studies on the subject). A substantial body of empirical evidence documents the superior efficiency of private firms relative to comparable public firms and the improvement of efficiency after privatization (see La Porta and López-de Silanes [1999] and Chong and López-de Silanes [2004] for comprehensive studies and Megginson and Netter [2001] for a large literature review on the manufacturing industry) which can lead to an increase in price, because productivity increases, and debt per unit sold decreases. Firms' strategies are also analyzed in Schargrodsky [2003] who compares public and private firms in the US newspapers industry and finds that private ownership lowers selling price. This results from different managers' strategies and tastes, such as the quality vs. diffusion trade-off, something that is observed in the public management literature (see Boyne [2002] for a review).

In the water industries, the link between ownership and performance has been widely studied. Most studies use data envelopment analysis or stochastic frontier analysis (or a mix of both) or cost-functions and total factor productivity analyses). Renzetti and Dupont [2003] reviews different studies linking ownership and performance in France, the UK and the USA. They find no compeling evidence of private utilities outperforming public utilities. The same conclusion is observed in the literature review of Walter, Cullmann, von Hirschhausen, Wand, and Zschille [2009]. In their literature review of the quantitative studies of water utilities, Berg and Marques [2011] found that out 47 studies focusing on the ownership issue, 18 of them concluded that private water utilities were more efficient while 17 of them showed inconclusive results. An interesting result can be underlined in the paper by Suarez-Varela, Garcia-Valinas, Gonzalez-Gomez, and Picazo-Tadeo [2017] who use a data envelopment analysis to compute the technical efficiency of water utilities in Spain. Their results show that private management is more efficient in the use of labour input but less efficient at managing operational costs. This result is somehow similar to Saal and Parker [2000, 2001] who study the privatization of water utilities in England and Wales in 1989. Using cost function and Total Factor Productivity analyses to a panel of ten UK private companies, the authors conclude that there is no statistically significant reduction in the trend growth rate of total costs following privatization using cost function and no changes in productivity after privatization.

There are also many articles studying the relationship between ownership and price. Chong, Huet, Saussier, and Steiner [2006] use a 5,000 French municipalities' database for 2001 and find ceteris paribus an 11-euro premium of private management relative to the direct public management on baseline bills of 120 cubic 
meter consumption. This result is confirmed by Carpentier, Nauges, Reynaud, and Thomas [2006] using treatment effects. They however conclude that private management copy with harder operating environments. Both papers conclude that local governments are keener to contract out the management of water public services if they are more technically difficult to provide. A recent study by Chong, Saussier, and Silverman [2012] shows that over the 1998-2008 period, contracting out has a positive impact on price but the impact narrows or disappears when one considers big cities, as they have probably more capabilities to negotiate contracts with private operators.

The price premium of private management is also found in other countries. In Spain, Martinez-Espineira, Garcia-Valinas, and Gonzalez-Gomez [2009] use a treatment effects model on a sample of 53 major urban municipalities and found that there is a singificant positive impact of privatisation on prices. Using a set of 386 Southern Spanish municipalities, García-Valiñas, González-Gómez, and PicazoTadeo [2013] deal with an original framework in which externalization can be done through institutionalised public-private partnerships, whereby capital is shared between the public and private sector, or contractual public-private partnerships, which are similar to concessions. The results show that prices are higher under contractual public-private partnerships and institutionalised public-private partnerships than under direct management. Using a database of 765 German water suppliers, Ruester and Zschille [2010] also found that private sector participation increases price in Germany. On the contrary, Romano, Masserini, and Guerrini [2015] show that in Italy ownership does not influence the tariffs levied by water utilities.

The water public service in France is a good candidate for an empirical study of the impact of contracting out on price for several reasons. First, tap water is a quasi-homogeneous good with very little differences in quality ${ }^{1}$. Second, the market for water distribution is large, covering the whole French population. Third, private sector participation has been growing since the 1980s. As private firms now serve more than $60 \%$ of the French municipalities, the impact of private participation can thus be large. Fourth, there are no secondary markets that can mitigate the impact of the private sector participation or transfer it to other markets, as such was the case in telecommunications or wireless internet access. Finally, perhaps the most salient motivation for investigating this industry is that contracting out has been drawing a lot of attention in the media with several non-governmental organizations praising remunicipalizations. This paper contributes to the large literature on the comparative economics of direct management and contracting out in public services.

The present study has several policy implications. First, municipalities and private operators have to be aware that when they benchmark prices, they should account for the differences of the water service's debt, which could lead to increases of prices in the future. Debt of the municipality has largely been recognized as a determining factor explaining the propensity to contract out. However, to the best of our knowledge, the debt of the public service per se has never been taken into account as a result of the organizational form. Second, it might explain the relative stability of private sector participation which has higher prices but lower hidden costs.

\footnotetext{
${ }^{1}$ Water quality in France has long been guaranteed and is drinkable across the whole French territory, even in overseas territories.
} 
The paper is organized as follows. Section 2 presents water provision regulation and section 3 presents the dataset. Section 4 describes the empirical strategy and the results of the impact of contracting-out on price. Section 5 discusses potential extensions and concludes the paper.

\section{Institutional Context}

\subsection{The Provision of Water in France}

Water provision refers to the production and the distribution of water and sewage implies wastewater collection and treatment. Water provision and sewage are two distinct public services and can be managed by two different operators. We focus in this paper on water provision. The responsibility for public services' provision is public, however its management can be either public or private. Although some municipalities manage production through direct public management and undertake all operations and investments needed for the provision of the service, the dominating organizational form is private management. Under private management, the main contractual form is lease contracts.

An official report by Dexia, a French financial intermediary, states that $63 \%$ of French medium-sized cities contract out the services of drinking water treatment and distribution and $58 \%$ also contract out their sewerage services. It is however difficult to have an accurate estimation of how many municipalities and communities have contracted out both services with the same operator. According to the Cour des Comptes [2011], the highest financial court in France, $71 \%$ of the population is covered by a private operator for water provision and $56 \%$ for water sewage. In this case a private operator, independent of the local government, is hired to manage the service and operate facilities through one of the four different private-public arrangements. The most common is the lease contract in which the operator manages the service, invest in the network and gets a financial compensation through consumer receipts. Under a concession contract, the external operators also undertakes construction risk, as it must finance a large part of investments over the duration of the contract. These contractual agreements differ from the previous ones in that operators share risk in exchange for greater decision rights and claims on revenues. In this study, we focus on lease contracts only because concession contracts imply investments on the infrastructure that would not be accounted for in the supplementary budget. As in France the infrastructure remains public, investments on the infrastructure are usually undertaken by the municipality. Under a lease contract, the private operator might give the municipality a part of its revenues to fund some investments or might be delegated to undertake the given investments in exchange of a fee funded by the tariff.

Contrary to other industrialized countries, there is no price-cap or rate-of-return regulation for water utilities in France as there is no national regulator. Such regulation has been replaced by a contract in the case of a private operator, or a decision of the municipality board in the case of public operation. In the case of delegated management, rules have been defined to ensure that standards are respected during the operation to limit the opportunistic behavior of operators and preserve competition between firms. First, since the "Sapin Law" 2 (1993) a national legislative

${ }^{2}$ Law 93-122 of the 29th of January 1993 on the prevention of corruption and the promotion of 
framework governs the form of the private sector participation and the conduct of the bidding process. The institutional framework to select the private partner is the following. If the public authority chooses a lease or a concession contract, it selects its partners in two steps. First, the public authority launches a classical invitation to tender which is open to all interested private water companies. Second, there is a negotiation phase between the public authority and potential shortlisted entrants. At the end of the negotiation, the public authority chooses its final partner for the duration of the contract. The selection of the private company follows the intuitu personae principle according to which the municipality or the community sets a list of criteria to select the firm that is considered as the best partner ${ }^{3}$.

Second, a strong regulation on contract duration and delegatee's obligations has been implemented in 1995 with the "Barnier Law"4. As a matter of fact, water quality in France has increased and is now relevant for more than $99 \%$ of the tests and a lot of investments have been made to prevent leaks. However, because regulation is made through contracts between the two parties, depending on the respective power of negotiators and with some contracts signed a century ago, there are doubts about the possibility of the parties to regularly adapt the tariffs to the needs of the municipality.

Furthermore, rules have been defined to ensure that standards are respected during the operation to limit the potential opportunistic behavior of operators. These rules support water quality, duration of contracts and information about management and provision quality. In the case of water quality, a precise definition of more than 60 verifiable quality parameters has been set by the 1992 Water Act $^{5}$ to ensure that water services, would they be private or public, respect quality standards. Consequently, water quality is respected and is rarely below a $95 \%$ score of conformity to the standards of the microbiological analysis. Moreover, limits on duration have been implemented and management and provision information is now required to be publicly reported. To ensure competition among operators, the "Barnier Law"(1995) clearly limit the duration of contracts to 20 years and includes an automatic renegotiation of the contract every five years. To struggle against information asymmetries, the executive power passed a decree in $2007^{6}$ that forces municipalities and communities to provide 14 performance indicators in the mayor's Annual Report on Prices and Service Quality (RPQS in French). These performance indicators and other data about water and sewerage services have been collected from 2009 on by the French National Observatory of Water and Aquatic Environments (ONEMA in French) to provide users and citizens with information about their water services.

\section{$2.2 \quad$ Price Setting}

Local authorities are concerned by price in their water-management decisions, because prices are observable by consumers and the popular press. Local authorities and the press tend to take price as the main indicator of performance to benchmark

\footnotetext{
transparency in the economic life and public procedures.

${ }^{3}$ However, the number of bidders remains low, around 1.9 for each bidding process (Guérin-Schneider and Lorrain [2003]).

${ }^{4}$ Law $95-101$ of the 2nd of February 1995 for protecting the environment.

${ }^{5}$ Law $92-3$ of the 3rd January 1992 on Water.

${ }^{6}$ Decree of the 2nd of May 2007 relative to the Annual Reports on Prices and Service Quality of Water and Sanitation.
} 
water services.

Under direct public management, the municipality council designs rates in order to generate revenues that allow the utility to cover its costs. French legislation requires the water utility budget to be balanced following the so-called "full-costs recovery" principle ${ }^{7}$. Prices are thus set to cover operating and capital $\operatorname{costs}^{8}$. Administrative account rules are devised so that municipalities hold two separate accounts for the water utility budget. The first account is an operating budget and the second is an investment budget. Net revenues from the operating budget are automatically transferred to the investment budget in order to limit operating costs. This is usually the case if the municipality undertakes a multi-year investment program. While the "full-costs recovery principle" usually implies a zero-margin cost structure, margins are however possible but the way they are used is highly controlled by administrative rules, i.e. margins cannot be used to increase the amount of the operating budget. The full-costs recovery principle is also applied to limit losses, particularly because city councils might be keen on spending more, because of their soft budget constraint (Kornai [1986]), or in order to keep prices at a low-level.

Under private management, the rate structure is determined by projecting financial accounts provided by the operator over the duration of the contract. The contract includes periodic revisions of water rates using a price index adjusting formula. The relationship between the local municipality and the firm is formalized by means of a contract that specifies a price structure, a formula of price revision and negotiated clauses allowing for exceptional conditions. Since the bargaining power is often considered to be favorable to firms, the price structure is likely to reflect a monopolistic behavior rather than social welfare maximization. In the case of delegated management, public authorities face the classic regulatory problem: they find themselves in an information asymmetry position and have few tools to carry out their essential tasks. However, rules have been implemented to limit opportunistic behavior by private operators. For example, in renegotiating prices, operators are constrained by the fact that in administrative contracts, all renegotiations that significantly change the value (by more than $5 \%$ of the value of the initial contract) of the contract trigger a new selection process of the private operator. Even if this power is rarely used, it provides a credible power to local authorities in order to prevent opportunistic behavior from an operator.

Private operators are often pointed by the media as practicing overpricing and getting excessive margins. Excessive pricing can be considered as distortions (e.g. Zschille and Walter [2012] and Le Lannier and Porcher [2014]) between producers and consumers because it could mean that prices are set above marginal costs or that producers 'overprice' the good, creating a deadweight loss (Porcher [2014] and Porcher, Molinos-Senante, and Maziotis [2017]).

\footnotetext{
${ }^{7}$ Article L2224-1 of the Code Général des Collectivités Territoriales, the French General Local Authorities Code.

${ }^{8}$ There is little historical evidence of the application of this principle. However as large cities' accounts are now published every year, there is strong evidence of the application of this principle in recent years. The highest financial court in France, the Cour des Comptes [2011], has notified several municipalities that their rates were too high, therefore using municipal budgets to fund non-water spendings, or too low, i.e. subsidized by another municipal budget.
} 


\subsection{Debt of Water Utilities}

Several studies such as Levin and Tadelis [2010] or Klien [2015] use municipal debt as a political economy variable.. For Levin and Tadelis [2010], a political view would suggest that municipalities which are constrained by outstanding debt may be more likely to contract out to save costs. A similar view developed by Beuve and Le Squeren [2016] is that the level of public services is determined by the financial resources of the municipality. As the ability to raise taxes is implicitly limited, municipalities with high level of debt tend to outsource public services. For Klien [2015], as public enterprises are typically under the control of politicians, they can be used to pursue political goals such as setting price below the marginal cost for electoral reasons or, on the contrary, price above the marginal cost to fund other public services or the municipal budget. In this view, prices are used as instruments of reelection. All these studies see municipal debt as a political economy instrument.

To the best of our knowledge, there are no studies relating the performance of a given public service by connecting it with the level of debt of the public service per se, rather than the debt of the municipality. Indeed, in France, public services such as water, waste and public transport, have their own budget ('supplementary budget' or 'budget annexe' in French) which is appended to the budget of the municipality. Such a supplementary budget means that all the costs of the water industry must be covered by the price paid by consumers. This means that if the price does not cover the costs, the supplementary budget is in deficit, creating a debt for the public service, which cannot be refunded by increasing local taxes or using the surpluses of some other supplementary budgets (such as sanitation or transportation). Directly managed public services are typically expected to have lower prices than contracted-out services but higher debt of the supplementary budget because city councils are reluctant to increase prices in the short-term. On the contrary, under lease contracts, private firms would tend to have higher prices than directly managed public services but lower debt of the supplementary budget. The hypothesis tested in the paper is thus that organizational form is neutral, i.e. directly managed and contracted-out services have the same prices if we account for the 'hidden costs', i.e. the price accounting for supplementary debt refunding. The next section explains how the 'hidden costs' can be computed for.

\section{Data}

Our dataset is built from the information contained in the Annual Reports on Prices and Service Quality (Rapport Prix-Qualité Service in French) which were collected for the 300 French water services covering more than 20,000 inhabitants. We had 177 complete reports. Because of missing data on the debt of water public services, which is in most cases hidden information, our unique sample for this study is made of 115 observations - 63 lease contrats and 52 directly managed services - accounting for a sixth of the French population.

The database includes a lot of information about water supply at the servicelevel - e.g. billed water, water sources, treatments and municipalities' characteristics which can influence water consumption. It also includes some data coming from the 
census made by the French National Institute for Statistics and Economic Studies. We know for example whether the city is located in a touristic area or in which administrative region the city is located. The latest variables are important controls when one tries to explain the price of water: on the one hand, touristic areas face larger levels of consumption during some periods of the year and need more performing networks; on the other hand, water consumption differs from a region to another, e.g. for climatic reasons.

An important feature of our dataset is that, in addition to characteristics about the contract such as the organization of the public service, it provides high-quality information about water bill structure. The standard consumption is 120 cubic meter a year per household as defined by the National French Statistics Institute. At the baseline consumption level, we know for example the price paid by consumers, the amount of the fixed-part and the amount of the variable part of the water tariff ${ }^{9}$. More importantly for this study, our data collection allowed us to collect information on the level of debt of public services in order to compute the hidden cost of water.

Table 1 gives a comparison of debt, debt per customer, and rescheduled annual debt payments under alternative assumptions on the length of the repayment. Water budget's debt is largely higher in municipalities under public management than in privately managed water industries as Table 1 shows. For simplicity's sake, we assume that debt interest rates are fixed, at $2 \%$, a largely validated hypothesis ${ }^{10}$ that corresponds to what is observed in the data. Table 1 shows the hidden costs of water under two different maturities, 5 or 10 years old. This choice is justified by the fact that the median duration is 12 years and the number of years before the end of the contract is 6 years in $2008^{11}$. Under a 10-years refunding hypothesis, annual debt payments per customer would increase by 35.52 euros under direct management and 14.81 euros under contracting-out. Under this hypothesis, the remaining differences in prices between direct and contracted-out management would almost be cleared-up. Under a 5-years refunding hypothesis, the difference of rescheduled annual payments per customer increases, the difference being almost 40 euros between the two types of organization of the production. One can thus consider that municipalities which contracted out have borrowed less or for shorter terms than municipalities under direct management. It clearly seems that the longer is the refunding of the debt and the lower is the difference between in favour of direct management. A simple look at Panel (A) in Table (1) shows that under a 10-years hypothesis, direct management becomes less expensive than private management. The differences in annual debt payments are used to compute the hidden costs under alternative hypotheses - a direct refunding of debt, after 5 or 10 years - as shown in the descriptive statistics.

Descriptive statistics relative to the price of water and the main drivers of costs are presented in Table 2. The main result from the descriptive statistics can be

\footnotetext{
${ }^{9} \mathrm{An}$ assumption that is related to the computation of the marginal price is that there is no multi-tier rates in water industries for consumption that are close to the baseline level. This assumption holds for French water industries, see Porcher [2014].

${ }^{10}$ State debt is on average refunded at $2.02 \%$ but only $1.3 \%$ on the short-term debt. Municipalities usually face rates at $2 \%$ in my dataset but it depends on their debt structure, i.e. whether they borrow to private or public banks or other public operators.

${ }^{11}$ These figures are based on descriptive statistics from the IFEN-SoAS dataset which is used in Porcher [2012] and Chong et al. [2012] for example.
} 
summarized as follows: contracted-out services face higher prices but also higher costs. Panel (A) describes the difference of prices between direct management and contracted-out services. On the one hand, direct management is characterized by a lower standard price, i.e. 124 euros for an annual bill per household versus 154 euros in contracted-out services. If we look at the hidden costs of water, the difference is in favor of contracting out if we assume an immediate refunding of the water debt or if we schedule the refunding under a 5-year hypothesis. In this latter case, there is a price premium of 7 euros in favor of contracting out for an annual bill of 207 euros on average. Under a 10-year hypothesis, the refunding would leave a price premium of 12 euros in favor of direct management, showing that the longer is the debt refunding, the more advantaged are directly managed services.

Panel (B) in Table 2 illustrates how private management is associated with more difficult services, which could explain part of the price premium. For example, surface water is usually associated with higher treatment complexity because it is more polluted than underground water. Overall, surface water is associated with higher production costs compared to underground water. Water treatments performed by the operator before the water is distributed are important cost-shifters. Indeed, water treatment does not only approximate the complexity of service provision but also the level of specific investments needed to operate the service. Underground water is generally more stable over time and has two advantages: it reduces uncertainty about the evolution of costs and its treatment costs are usually lower. Under mixed sources of water, costs may be higher than for surface or underground sources as the utility may need a treatment factory for each type of water. There are six types of treatments in our dataset corresponding to five dummy variables. In the simplest case, there is no treatment. When raw water needs disinfection, we use the dummy variable Treatment 2. Treatment 3 means that raw water needs a heavy disinfection treatment and Treatment 4 that water needs a heavy disinfection treatment plus extra controls. Treatment 5 and Treatment 6 refer to mixed treatments, the most difficult treatment being 5 . Overall, descriptive statistics show that contracted-out services are associated with higher complexity which can explain differences in costs and thus in prices.

The last column of Table 2 shows the difference between private and public management. A star indicates a significant difference between the two means, using a t-test. Rescheduled prices are not significantly different, unless the debt has to be refunded immediately. It shows that our sample of directly managed and contracted out services is relatively homogenous. Because of the homogeneity of the sample, the variable capturing the organizational form - direct management vs. lease contract - is thus expected to be the main explanation for price differences.

\section{Empirical Strategy}

Our objective is to identify the average effect of private participation on the price of a standard bill of residential water use. We are specifically interested in comparing prices for a standard bill when water services are privately operated (our treatment group) compared to directly managed water services (our control group) at the same moment in time. To control for the unobserved heterogeneity and the unobserved time invariant heterogeneity we include administrative regional fixed effects and robust standard errors. We first run a simple OLS model: 


$$
\text { Price }_{i t}=\alpha_{0}+\alpha_{1} \text { Private }_{i t}+\gamma \Theta_{i t}+\eta_{i t}
$$

with price Price $_{i t}$ as a dependent variable, Private $_{i t}$ a dummy that equals 1 when water is distributed by a private operator and $\Theta_{i t}$ a set of controls that can shift prices. There are however several assumptions that should be made in order to correctly interpret $\alpha_{1}$ in equation (1) as Galiani, Gertler, and Schargrodsky [2005] noticed. The first assumption is that price in municipalities under public management is an unbiased estimate of the counterfactual - i.e. that it represents the price in municipalities under private management if water services were directly managed. The second assumption is that there are no unobserved characteristics that can affect both prices and the decision to contract out. Another concern is that the average impact of contracting out may not be homogeneous across municipalities. In this case, our estimation in equation (1) can be biased. One of the assumptions underlying the interpretation of the coefficients of equation (1) is that municipalities under public and private management are similar. Including controls is a good way to purge structural differences between observations but it does not mimic a differences-in-differences approach by estimating the impact of organizational changes assuming similar trends. Moreover, there might be a selection effect in our dataset as debt of the water public services is rarely reported in the official reports we had access to. However, due to the focus on large water public services and to the representativeness of the dataset in terms of contracting-out proportions and size of the served population, the results extracted from a simple OLS model are already of interest.

In order to control for the selection effect due to the missing information on water public services debt, we run a simple Heckman [1979] selection model, which accounts for potential selection biases in the collection of the data. In the first stage, we use a Probit model of the probability for a municipality of having the information on debt fulfilled as a function of explaining variables. The selection equation is:

$$
V_{i}=\beta_{0}+\beta Z_{i}+\eta_{i}
$$

where $V_{i}$ is a latent variable equal to one if the information on the debt of water public services was fulfilled and 0 if the information was not reported, $\beta$ the vector of coefficients for the selection equation, $Z_{i}$ the vector of covariates for city $i$ and $\eta_{i}$ the random disturbance for a given city $i$. The vector of covariates includes the organizational form (public or private), the size of the population, the density of the network and dummies equal to 1 if the information on the main regulatory indicators - rate of complaints, rate of unforeseen service interruptions, indexes of water protection and network knowledge - is fulfilled and 0 either. Descriptive statistics are reported in appendix. From this equation, we compute the inverse Mills ratio that is added as a variable in the second-stage equation, which is similar to equation (1), in order to account for the potential selection effect.

Table 3 reports the results for equation (1). Model (1) shows the mean difference of price between direct management and contracting-out when we take into account all controls. While the gap between average prices is 30 euros, accounting for various characteristics of the municipality lowers it to 31.9 euros. Models (2), (3) and (4) show the results when we use the different prices as dependent variables, i.e. respectively the price assuming a complete refund of debt in the first year, then the price under a 5-years refunding hypothesis and finally the price under a 
10-years refunding hypothesis. Our results show that the price premium becomes non-significant when we account for the differences in the levels of debt under the 5and 10-years refunding hypotheses. In Model (2), i.e. if the debt had to be refunded in a given year, contracting out would clearly have a negative impact on price, i.e. decreasing the price by 202.16 euros because direct management is characterized by a debt per capita far more higher than contracted-out services. The coefficient is positive in Model (3), showing a non-significant but positive impact of direct management if the debt had to be refunded in the five coming years. In Model (4), the coefficient is non-significant but negative showing that direct management can have a negative effect on price because the debt is set to be refunded under more than 10-years. Overall, our results show that contracting-out increases price if one does not account for the debt of the public service but that it decreases price or has a neutral effect when we account for the debt of the public service.

Controls, except density and water quality, have no significant impact. This is due to at least two reasons. The first reason is that, due to the size of our sample, regional dummies might capture some of the service-level effects. The second reason is that we have a subsample of water services which are relatively homogenous in terms of size but also complexity (see Table 2). The only difference is usually the price, the level of debt and the organisational form, which explains our results.

Table 4 reports the coefficients of the impact of direct management on the different prices computed after accounting for the selection equation. The main conclusions are not affected by the potential biases in the selection of the data. In Model (1) of Table 4, the gap between direct management and contracting out is even bigger than in simple descriptive statistics, respectively 36 euros versus 33 euros. The effects are similar in Models (2), (3) and (4) for the two different models showing that there is at least no selection problems between our sample of 177 and the sample used in the study. We report sensitivity analyses in Table 7 under different interest rates and debt maturities. Overall, it seems that public and private management have the same price, including hidden costs, when debt maturity is 7 or 8 years old.

\section{Discussion and Conclusion}

In this paper, we analyzed the impact of contracting out on price in residential water supply. We found that private management is on average more expensive for customers than direct management, everything else being equal, when we account for the billed price. However, when we consider the level of debt and thus the potential increases in price in the following year to refund the debt, we find no significant differences between direct management and contracting out. If the debt of the public service were to be refunded in a given year, there would be even a huge price premium - equal to an annual bill - in favor of contracting out. Our results thus show that direct management is characterized by lower prices which are actually funded by a higher level of debt, while contracted-out services have higher prices but a lower level of debt. Contrary to a widespread idea, higher prices observed under lease contracts might not be related to excessive margins from private operator but to their account of the full-costs recovery principle. On the contrary, under direct management, city councils are more reluctant to increase prices so they would tend to increase debt of the water public service. In the end, our research shows that 
under a $2 \%$ interest rate and the current levels of debt, the loan maturity should be between 7 and 8 years-old.

Our research carries several policy implications. First, municipalities must be aware that contracting out might impact the price, but not in the proportion they expect. Second, comparing municipalities between one and another imposes a reasonably similar sample in terms of observables and to account for the hidden costs of water. Third, it shows the importance of collecting data to put more lights on the debate on public services' reforms, especially on the contracting out versus direct management debate. Furthermore, our results show that public and private organizations may not reflect the same goals. Such a link between ownership and strategy is early discussed in Williamson [1963] who considers that managers can have expense preferences that are discretionary. Public and private management may want to use pricing strategy to indulge their consumption preferences. For example, public managers may want to decrease prices for consumers and fund a part of its investments using debt for bureaucratic reasons. Private managers may seek to maximize their profits to satisfy stockholders. These arguments are used in many studies comparing public and private ownership such as in La Porta and López-de Silanes [1999], Schargrodsky [2003] and Peng, Tan, and Tong [2004].

There are of course limitations to our results. The main limitation of our study is that it is focused on large water services France in 2009. As shown in the descriptive statistics, the observations share similar characteristics which is a good point for comparison, as the main differences between the studied services are the price, the debt and the organizational form. Our results would probably different if we had included small water public services as city councils and private operators' strategies could be different. One of the features of large municipalities is that we expect local governments to have capabilities in managing contracts. Small local governments might be less at ease in dealing with public services debt or negotiating contracts with private operators. Further research could extend the dataset and increase the number of years to have a dynamic perspective on the evolution of debt through the life of the contract.

There are also missing variables such as unemployment or population's ideology. The unit of observation of our dataset - the contract-level rather than the municipal-level - makes data collection difficult. While municipal-level data is easy to collect via the census data, contract-level data is difficult to compute because the geography of contracts does not follow the one of municipalities. For example, Paris used to have two contracts for water for many years; the city of Nantes uses three different organizational forms for water provision across its territory. One might also argue that the ideological variables are important to explain the difference of price. Studies in France show no impact of ideology on price, measured as the score of leftwing parties at the last presidential elections on price (Chong et al. [2006], Chong et al. [2012]) or by the political ideology of the current mayor (Porcher [2012]). The external validity of the results is limited to countries with the same institutional context. However, we believe that this is precisely this institutional context which makes the study interesting and relevant. 


\section{References}

Armen A. Alchian and Harold Demsetz. Production, Information Costs, and Economic Organization. The American Economic Review, 62(5):777-795, 1972.

Sanford Berg and R.C. Marques. Quantitative Studies of Water and Sanitation Utilities: a Benchmarking Literature Survey. Water Policy, 13(5):591-606, 2011.

Jean Beuve and Zoe Le Squeren. When Does Ideology Matter? An Empirical Analysis of French Municipalities' Make-or-Buy Choices. Chaire EPPP Discussion Paper, 2016.

George A. Boyne. Public and Private Management: What's The Difference? Journal of Management Studies, 39(1):97-122, 2002.

A. Carpentier, Céline Nauges, Arnaud Reynaud, and Alban Thomas. Effets de la délégation sur le prix de l'eau potable en france: Une analyse à partir de la littérature sur les effets de traitement. Economie et Prévision, 3(174):1-19, 2006.

Doug W. Caves and Laurits R. Christensen. The Relative Efficiency of Public and Private Firms in a Competitive Environment: The Case of Canadian Railroads. Journal of Political Economy, 88(5):958-976, 1980.

Alberto Chong and Florencio López-de Silanes. Privatization in Latin America: What Does the Evidence Say? Economia, 4(2):37-111, 2004.

Eshien Chong, Freddy Huet, Stéphane Saussier, and Faye Steiner. Public-Private Partnerships and Prices: Evidence from Water Distribution in France. Review of Industrial Organization, 29:149-169, 2006.

Eshien Chong, Stéphane Saussier, and Brian Silverman. Water Under the Bridge: When and How Do Municipalities Change Organizational Forms in the Provision of Water? Chaire EPPP Discussion Paper, 2012.

Cour des Comptes. Les services publics d'eau et d'assainissement: des evolutions encourageantes. Report, Cour des Comptes, 2011.

D.G. Davies. The Efficiency of Public versus Private Firms, the Case of Australia's Two Airlines. Journal of Law and Economics, 14(1):149-165, 1971.

Sebastian Galiani, Paul Gertler, and Ernesto Schargrodsky. Water for Life: The Impact of the Privatization of Water Services on Child Mortality. Journal of Political Economy, 113(1):83-120, 2005.

M. García-Valiñas, F. González-Gómez, and A.J. Picazo-Tadeo. Is the Price of Water for Residential Use Related to Provider Ownership? Empirical Evidence From Spain. Utilities Policy, 24:59-69, 2013.

L. Guérin-Schneider and D. Lorrain. Les relations puissance publique-firmes dans le secteur de l'eau et de l'assainissement. Flux, (52-53):35-54, 2003.

James J. Heckman. Sample Selection Bias as a Specification Error. Econometrica, 47(1):153-161, 1979.

Michael Klien. The political side of public utilities: How opportunistic behaviour and yardstick competition shape water prices in austria. Papers in Regional Science, 94(4):869-890, 2015.

Janos Kornai. The Soft Budget Constraint. Kyklos, 39(1):3-30, 1986. 
Rafael La Porta and Florencio López-de Silanes. The Benefits of Privatization: Evidence from Mexico. The Quarterly Journal of Economics, 114(4):1193$1242,1999$.

Aude Le Lannier and Simon Porcher. Efficiency in the Public and Private French Water Utilities: Prospects for Benchmarking. Applied Economics, 5(46):556$572,2014$.

John D. Levin and Steven Tadelis. Contracting for Government Services: Theory and Evidence from US Cities. Journal of Industrial Economics, 58(3):507-541, 2010.

R Martinez-Espineira, M Garcia-Valinas, and F Gonzalez-Gomez. Does Private Management of Water Supply Services Really Increase Prices? An Empirical Analysis. Urban Studies, 46(4):923-945, 2009.

William L. Megginson and Jeffry M. Netter. From State to Market: a Survey of Empirical Studies on Privatization. Journal of Economic Literature, 39:321389, 2001.

Mike W. Peng, Justin Tan, and Tony W. Tong. Ownership Types and Strategic Groups in an Emerging Economy. Journal of Management Studies, 41(7): 1105-1129, 2004.

S Porcher, Maria Molinos-Senante, and Alexandros Maziotis. The welfare costs of non-marginal water pricing: Evidence from the water only companies in England and Wales. Urban Water Journal, 0(0):1-7, 2017.

Simon Porcher. Organizational Choices, efficiency and equity in local public services: the case of French water supply. PhD thesis, Université Paris PantheonSorbonne, 2012.

Simon Porcher. Efficiency and Equity in Two-Part Tariffs: The Case of Residential Water Rates. Applied Economics, 5(46):539-555, 2014.

S. Renzetti and D. Dupont. Ownership and Performance of Water Utilities. The Journal of Corporate Environmental Strategy and Practice, 42:9-19, 2003.

G. Romano, L. Masserini, and A. Guerrini. Does Water Utilities' Ownership Matter in Water Pricing Policy? An Analysis of Endogenous and Environmental Determinants of Water Tariffs in Italy. Water Policy, 17(5):918-931, 2015.

S Ruester and M Zschille. The Impact of Governance Structure on Firm Performance: An Application to the German Water Distribution Sector. Utilities Policy, 18(3):154-162, 2010.

David S Saal and David Parker. The Impact of Privatization and Regulation on the Water and Sewerage Industry in England and Wales: a Translog Cost Function Model. Managerial and Decision Economics, 21(6):253-268, 2000.

David S Saal and David Parker. Productivity and Price Performance in the Privatized Water and Sewerage Companies of England and Wales. Journal of Regulatory Economics, 20(1):61-90, 2001.

Ernesto Schargrodsky. Do Publicly Traded Firms Price Differently from Private Firms? American Law and Economics Review, 5(1):32-60, 2003.

M Suarez-Varela, M Garcia-Valinas, F Gonzalez-Gomez, and A.J. Picazo-Tadeo. Ownership and Performance in Water Services Revisited: Does Private Management Really Outperform Public? Water Resources Management, 31, 2017.

Aiden Vining and Anthony Boardman. Ownership and Competition: Efficiency in Public Enterprise. Public Choice, 73(1):205-239, 1992. 
Matthias Walter, Astrid Cullmann, Chris von Hirschhausen, Robert Wand, and Michael Zschille. Quo Vadis Efficiency Analysis of Water Distribution: a Comparative Literature Review. Utilities Policy, 17(3-4):225-232, 2009.

Oliver E. Williamson. Managerial Discretion and Business Behavior. The American Economic Review, 53(5):1032-1057, 1963.

Michael Zschille and Matthias Walter. The Performance of German Water Utilities: a (semi)-Parametric Analysis. Applied Economics, 44(29):3749-3764, 2012. 
Table 1: Water Public Service Debt and Rescheduled Annual Debt Payments (ADP), in euros

\begin{tabular}{|c|c|c|}
\hline & Direct Management & Contracted Out \\
\hline Water Debt (in '000 euros) & $\begin{array}{c}7,211.44 \\
(9,211.50)\end{array}$ & $\begin{array}{c}3,196.70 \\
(5,241.32)\end{array}$ \\
\hline Water Debt per Customer & $\begin{array}{c}319.06 \\
(326.24)\end{array}$ & $\begin{array}{c}133.04 \\
(182.12)\end{array}$ \\
\hline Rescheduled ADP per Customer, under 5-year hyp. & $\begin{array}{c}67.69 \\
(69.21)\end{array}$ & $\begin{array}{c}28.23 \\
(38.64)\end{array}$ \\
\hline Rescheduled ADP per Customer, under 10-year hyp. & $\begin{array}{c}35.52 \\
(36.32)\end{array}$ & $\begin{array}{c}14.81 \\
(20.28)\end{array}$ \\
\hline
\end{tabular}

Note: Debt is expressed in thousands euros. Debt per customer and annual debt payments per customer are expressed in euros. Rescheduled debt annual payments are computed under two assumptions: a 5-year debt refund in the third raw and a 10-year debt refund in the fourth raw, both under a $2 \%$ debt interest rate hypothesis. Standard deviations are in parentheses. 


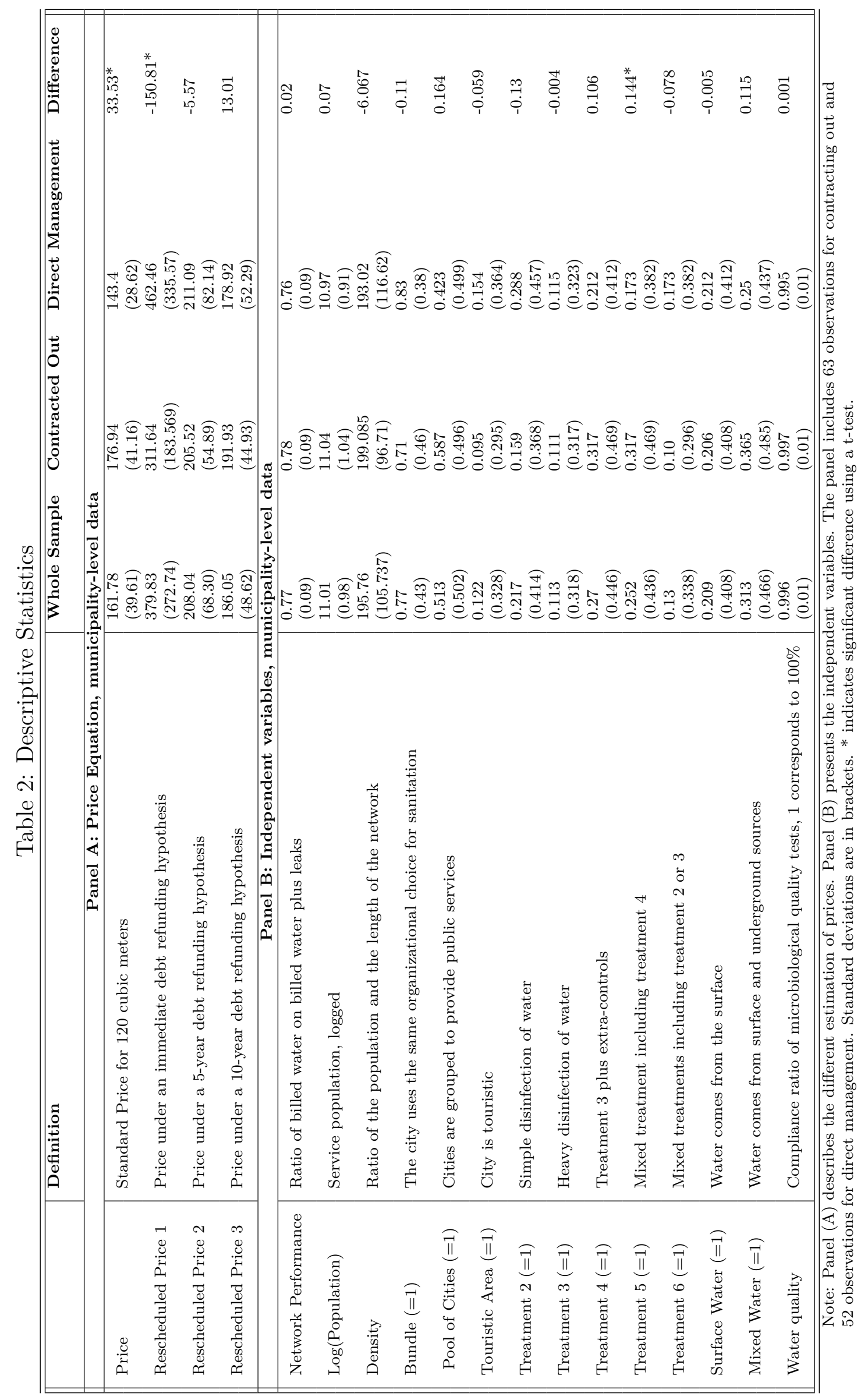


Table 3: The Impact of Private Management on Prices

\begin{tabular}{|c|c|c|c|c|}
\hline Variables & $\begin{array}{c}(1) \\
\text { Price }\end{array}$ & $\begin{array}{c}(2) \\
\text { Rescheduled Price } 1\end{array}$ & $\begin{array}{c}(3) \\
\text { Rescheduled Price } 2 \\
\end{array}$ & $\begin{array}{c}(4) \\
\text { Rescheduled Price } 3\end{array}$ \\
\hline Direct Management $(=1)$ & $\begin{array}{c}-31.895^{* * *} \\
(10.58)\end{array}$ & $\begin{array}{l}202.158^{* * *} \\
(77.71)\end{array}$ & $\begin{array}{l}17.761 \\
(18.97)\end{array}$ & $\begin{array}{l}-5.839 \\
(13.20)\end{array}$ \\
\hline Density & $\begin{array}{c}-0.0075 \\
(0.04)\end{array}$ & $\begin{array}{c}-0.783^{* *} \\
(0.30)\end{array}$ & $\begin{array}{c}-0.225^{* * *} \\
(0.08)\end{array}$ & $\begin{array}{c}-0.154^{* *} \\
(0.06)\end{array}$ \\
\hline Log(Population) & $\begin{array}{l}5.801 \\
(6.38)\end{array}$ & $\begin{array}{l}39.513 \\
(33.34)\end{array}$ & $\begin{array}{l}12.953 \\
(10.21)\end{array}$ & $\begin{array}{l}9.554 \\
(7.94)\end{array}$ \\
\hline Network Performance & $\begin{array}{l}-35.887 \\
(52.30)\end{array}$ & $\begin{array}{l}-366.775 \\
(401.08)\end{array}$ & $\begin{array}{l}-106.088 \\
(100.25)\end{array}$ & $\begin{array}{l}-72.724 \\
(69.36)\end{array}$ \\
\hline Bundle $(=1)$ & $\begin{array}{l}1.268 \\
(9.93)\end{array}$ & $\begin{array}{r}-52.305 \\
(87.14)\end{array}$ & $\begin{array}{r}-10.098 \\
(20.53)\end{array}$ & $\begin{array}{l}-4.696 \\
(13.52)\end{array}$ \\
\hline Pool of Cities $(=1)$ & $\begin{array}{l}-2.944 \\
(12.87)\end{array}$ & $\begin{array}{r}-54.822 \\
(72.65)\end{array}$ & $\begin{array}{l}-13.95 \\
(20.18)\end{array}$ & $\begin{array}{l}-8.79 \\
(15.36)\end{array}$ \\
\hline Touristic Area $(=1)$ & $\begin{array}{c}22.00 \\
(12.56)\end{array}$ & $\begin{array}{c}55.23 \\
(107.75)\end{array}$ & $\begin{array}{l}29.05 \\
(25.93)\end{array}$ & $\begin{array}{c}25.70 \\
(17.30)\end{array}$ \\
\hline Surface Water $(=1)$ & $\begin{array}{l}21.174 \\
(10.73)\end{array}$ & $\begin{array}{l}-33.429 \\
(91.51)\end{array}$ & $\begin{array}{l}9.589 \\
(21.93)\end{array}$ & $\begin{array}{l}15.095 \\
(14.63)\end{array}$ \\
\hline Mixed Water $(=1)$ & $\begin{array}{l}7.785 \\
(9.23)\end{array}$ & $\begin{array}{r}-18.328 \\
(84.56)\end{array}$ & $\begin{array}{l}2.245 \\
(20.72)\end{array}$ & $\begin{array}{c}4.878 \\
(13.72)\end{array}$ \\
\hline Treatment $2(=1)$ & $\begin{array}{l}-15.594 \\
(24.23)\end{array}$ & $\begin{array}{l}-572.385 \\
(129.38)\end{array}$ & $\begin{array}{l}-24.46 \\
(39.38)\end{array}$ & $\begin{array}{l}-20.246 \\
(30.45)\end{array}$ \\
\hline Treatment $3(=1)$ & $\begin{array}{l}-23.463 \\
(28.21)\end{array}$ & $\begin{array}{l}-101.033 \\
(194.69)\end{array}$ & $\begin{array}{l}-39.920 \\
(52.90)\end{array}$ & $\begin{array}{l}-32.098 \\
(38.11)\end{array}$ \\
\hline Treatment $4(=1)$ & $\begin{array}{l}-8.668 \\
(25.97)\end{array}$ & $\begin{array}{c}-3.193 \\
(155.43)\end{array}$ & $\begin{array}{l}-7.507 \\
(44.56)\end{array}$ & $\begin{array}{l}-8.059 \\
(33.40)\end{array}$ \\
\hline Treatment $5(=1)$ & $\begin{array}{l}1.097 \\
(26.23)\end{array}$ & $\begin{array}{c}81.311 \\
(183.56)\end{array}$ & $\begin{array}{l}18.115 \\
(49.19)\end{array}$ & $\begin{array}{l}10.027 \\
(35.25)\end{array}$ \\
\hline Treatment $6(=1)$ & $\begin{array}{c}4.167 \\
(28.24)\end{array}$ & $\begin{array}{r}-144.193 \\
(156.46)\end{array}$ & $\begin{array}{l}-27.309 \\
(45.83)\end{array}$ & $\begin{array}{l}-12.349 \\
(35.09)\end{array}$ \\
\hline Water Quality & $\begin{array}{c}1070.396^{* *} \\
(425.98)\end{array}$ & $\begin{array}{c}5909.575^{* *} \\
(2315.15)\end{array}$ & $\begin{array}{c}3097.069^{* * *} \\
(622.69)\end{array}$ & $\begin{array}{c}1609.125^{* * *} \\
(479.34)\end{array}$ \\
\hline Constant & $\begin{array}{c}-906.466^{* *} \\
(423.27)\end{array}$ & $\begin{array}{c}-5443.678^{* *} \\
(2343.58)\end{array}$ & $\begin{array}{c}-1869.074^{* * *} \\
(629.72)\end{array}$ & $\begin{array}{c}-1411.578^{* * *} \\
(481.80)\end{array}$ \\
\hline Regional FE & Yes & Yes & Yes & Yes \\
\hline Observations & 115 & 115 & 115 & 115 \\
\hline R-squared & 0.37 & 0.35 & 0.31 & 0.31 \\
\hline
\end{tabular}

Note: All models are OLS regressions. In Model (1), the dependent variable is the price for a standard bill of water for a given municipality. In Models (2), (3) and (4), the price accounting for hidden costs is used, respectively under an immediate refunding or a 5-years or a 10-years horizon refunding. Robust Standard Errors in Parentheses with ${ }^{* * *} \mathrm{p}<0.01,{ }^{* *} \mathrm{p}<0.05, *$ $\mathrm{p}<0.1$ for all models. 
Table 4: The Impact of Private Management on Prices - Controlling for selection biases

\begin{tabular}{||l|cccc||}
\hline \hline & $(1)$ & $(2)$ & $(3)$ & $(4)$ \\
Variables & Price & Rescheduled Price 1 & Rescheduled Price 2 & Rescheduled Price 3 \\
\hline \multirow{3}{*}{ Direct Management $(=1)$} & $-36.722^{* *}$ & $208.407^{* * *}$ & & \\
& $(14.746)$ & $(78.286)$ & 15.283 & -9.433 \\
Inverse Mills Ratio & 9.226 & -11.943 & $(20.565)$ & $(15.965)$ \\
& $(19.560)$ & $(138.045)$ & $(35.322)$ & 6.87 \\
& & & & $(25.07)$ \\
\hline Regional FE & Yes & Yes & Yes & Yes \\
Observations & 115 & 115 & 115 & 115 \\
R-squared & 0.47 & 0.41 & 0.39 & 0.38 \\
\hline \hline
\end{tabular}

Note: All models are OLS regressions using the inverse Mills ratio of the Heckman selection model. In Model (1), the dependent variable is the price for a standard bill of water for a given municipality. In Models (2), (3) and (4), the price accounting for hidden costs is used, respectively under an immediate refunding or a 5 -years or a 10 -years horizon refunding. Robust Standard Errors in Parentheses with ${ }^{* * *} \mathrm{p}<0.01,{ }^{* *} \mathrm{p}<0.05,{ }^{*} \mathrm{p}<0.1$ for all models.

\section{Appendices}

Table 5: Comparison of the variables in the selected and unselected groups

\begin{tabular}{||l|cc|}
\hline \hline & Selected (debt is fulfilled) & Not selected \\
\hline Direct Management $(=1)$ & 0.448 & 0.033 \\
& $(0.499)$ & $(0.180)$ \\
Log(Population) & 11 & 10.37 \\
Density & $(0.98)$ & $(0.63)$ \\
& 194.803 & 245.206 \\
Knowledge $(=1)$ & $(105.78)$ & $(147.09)$ \\
& 0.922 & 0.984 \\
Complaint $(=1)$ & $(0.269)$ & $(0.128)$ \\
& 0.871 & 0.951 \\
Interruption $(=1)$ & $(0.337)$ & $(0.218)$ \\
& 0.828 & 0.934 \\
Protection $(=1)$ & $(0.379)$ & $(0.25)$ \\
& 0.888 & 0.951 \\
& $(0.312)$ & $(0.218)$ \\
\hline \hline
\end{tabular}

Note: Standard deviations are in parentheses. 
Table 6: The determinants of having the information on service's debt fulfilled

\begin{tabular}{||c|c||}
\hline \hline Variables & $V$ \\
\hline Log(Population) & $0.678^{* * *}$ \\
& $(0.144)$ \\
Density & $-0.003^{* * *}$ \\
& $(0.001)$ \\
& -1.265 \\
Knowledge Fulfilled $(=1)$ & $(0.680)$ \\
& -0.048 \\
Protection Fulfilled $(=1)$ & $(0.476)$ \\
& -0.527 \\
Interruption Fulfilled $(=1)$ & $(0.490)$ \\
& 0.588 \\
Complaints Fulfilled $(=1)$ & $(0.562)$ \\
& $1.933^{* * *}$ \\
Direct Management $(=1)$ & $(0.424)$ \\
& $-5.076^{* * *}$ \\
Constant & $(1.628)$ \\
& 177 \\
$\mathrm{~N}$ & 0.34 \\
Pseudo $R^{2}$ & \\
\hline
\end{tabular}

Note: The model is a probit with a dummy equal 1 if debt is fulfilled and $\mathrm{O}$ in the other case as a dependent variable. Robust Standard Errors in Parentheses with ${ }^{* * *} \mathrm{p}<0.01,{ }^{* *} \mathrm{p}<0.05,{ }^{*} \mathrm{p}<0.1$ for all models.

Table 7: Sensitivity Analysis - The Impact of Public Management on Price

\begin{tabular}{||l|ccc||}
\hline \hline Variables & Interest Rate $=1 \%$ & Interest Rate $=2 \%$ & Interest Rate = 3\% \\
\hline Rescheduled Price, 3yrs & 46.627 & 48.277 & 49.938 \\
Rescheduled Price, 5yrs & 13.784 & 15.284 & 16.803 \\
Rescheduled Price, 7yrs & -0.289 & 1.153 & 2.622 \\
Rescheduled Price, 8yrs & -4.686 & -3.260 & -1.802 \\
Rescheduled Price, 10yrs & -10.841 & -9.433 & -7.986 \\
Rescheduled Price, 12yrs & -14.943 & -13.543 & -12.096 \\
Rescheduled Price, 20yrs & -23.139 & -21.731 & -20.246 \\
\hline \hline
\end{tabular}

Note: The table computes the impact of public management on price using the same Heckman selection procedure as the results reported in Table 4 for different debt maturities, respectively 3 years, 5 years, 7 years, 8 years, 10 years, 12 years and 20 years (in lines). Columns show the impact under different hypotheses on the interest rate. 